\title{
Pancreatic transection as a result of a high-pressure water jet injury
}

\author{
Ciaran Edward Redmond, ${ }^{1}$ Sinead Helena McEvoy, ${ }^{2}$ Edmund Ronan Ryan, ${ }^{2}$ Emir Hoti ${ }^{1}$
}

${ }^{1}$ Department of Hepatobiliary Surgery, St Vincent's University Hospital, Dublin, Ireland 2Department of Radiology, St Vincent's University Hospital, Dublin, Ireland

\section{Correspondence to}

Dr Ciaran Edward Redmond, ciaranredmond1@gmail.com
To cite: Redmond $C E$, McEvoy SH, Ryan ER, et al. BMJ Case Rep Published online: [please include Day Month Year] doi:10.1136/ bcr-2013-200403

\section{DESCRIPTION}

A 30-year-old man presented to our surgical department after sustaining a penetrating abdominal injury from a high-pressure water jet. The patient had been using a pressure washer to strip paint. The washer was operating at $3700 \mathrm{psi}$ when it malfunctioned causing a jet of water to strike him in the left upper quadrant of the abdomen. On arrival the patient was haemodynamically stable. He had severe upper abdominal pain. On examination there was a $1 \mathrm{~cm}$ entry wound located over his left upper quadrant. His abdomen was tender with marked crepitus palpable. His amylase was $303 \mathrm{U} / \mathrm{L}$ (reference range: $36-128 \mathrm{U} / \mathrm{L}$ ). A CT scan showed a pancreatic parenchymal injury involving almost the entire thickness of the pancreatic tail with associated transection of the pancreatic duct (figure 1), compatible with an American Association for the Surgery of Trauma (AAST) grade III injury. ${ }^{1}$ This was confirmed on MR cholangiopancreatography (MRCP) (figure 2). The patient was started on empiric antibiotics and underwent a diagnostic laparoscopy with peritoneal irrigation. He recovered well and was discharged after 12 days. Follow-up surveillance imaging demonstrated the development of a pancreatic pseudocyst. This was successfully managed with percutaneous drainage. At 9 months post injury, he is asymptomatic and has no radiological abnormalities of his pancreas.

Extremity injuries arising from high-pressure water jets are well recognised in the literature. However, there have been fewer reports of intra-abdominal injuries. ${ }^{2}{ }^{3}$ To our knowledge, this is the first report of a pancreatic injury due to a high-pressure water jet.

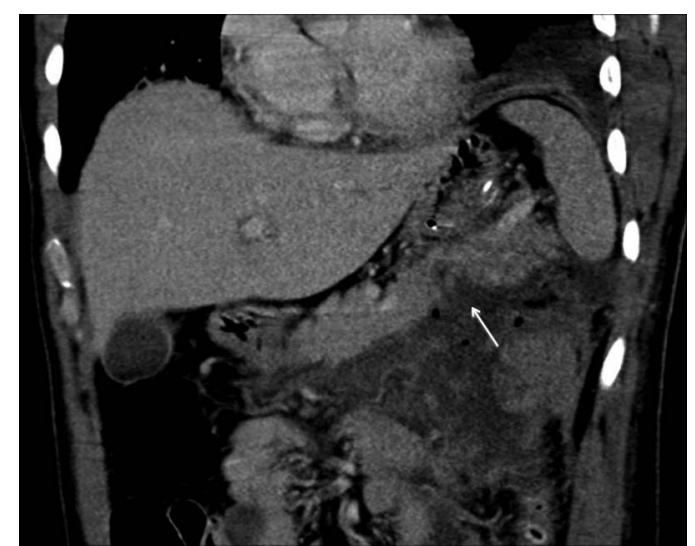

Figure 1 Coronal CT image through the upper abdomen shows extensive fluid between the body and the tail of the pancreas consistent with transection of the distal pancreas and suspicious for ductal involvement (arrow).

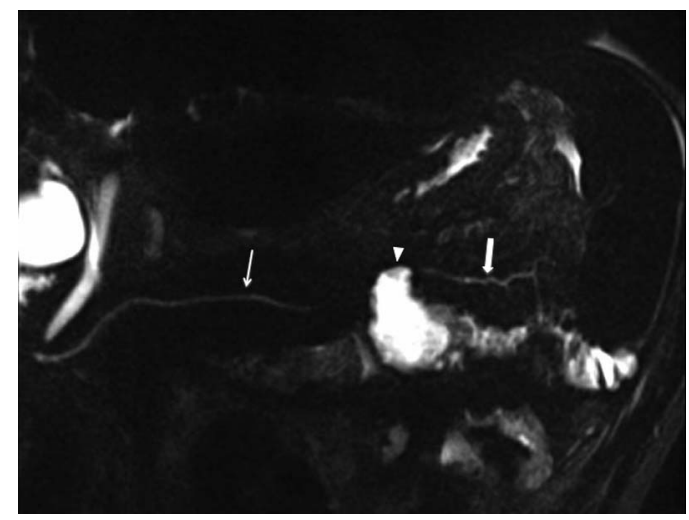

Figure 2 Coronal MR cholangiopancreatography image shows the main pancreatic duct (arrow) to be separate from the pancreatic tail duct (block arrow) with a large intervening retroperitoneal fluid collection (arrowhead) confirming transection of the distal pancreas with involvement of the pancreatic duct- American Association for the Surgery of Trauma grade III injury.

\section{Learning points}

High-pressure water jet injuries can cause significant internal damage with minimal external signs of trauma.

- Pseudocyst formation is well recognised following pancreatic ductal trauma.

- CT imaging and laparoscopy can have important roles in the investigation of a stable patient with penetrating abdominal trauma, potentially obviating an unnecessary laparotomy.

Contributors $C R, S M C E$, ERR and EH were involved in conception and design of the article. CR, SMCE and ERR contributed to acquisition and interpretation of data. CR and SMCE contributed to the drafting of the article. ERR and EH were involved in revising the article critically for important intellectual content. CR, SMCE, ERR and EH made final approval of the version published.

Competing interests None.

Patient consent Obtained.

Provenance and peer review Not commissioned; externally peer reviewed.

\section{REFERENCES}

1 Moore EE, Cogbill TH, Malangoni MA, et al. Organ injury scaling, II: Pancreas, duodenum, small bowel, colon, and rectum. J Trauma 1990;30:1427-9.

2 Sharma OP, Oswanski MF. Hydroblast intra-abdominal organ trauma. J Emerg Med 2002;22:49-53.

3 Costello MW, Bolling RP, Gonzalez RP. Intra-abdominal injury as a result of high-pressure water injection. J Trauma 2008;65:222-4. 
Copyright 2013 BMJ Publishing Group. All rights reserved. For permission to reuse any of this content visit http://group.bmj.com/group/rights-licensing/permissions.

BMJ Case Report Fellows may re-use this article for personal use and teaching without any further permission.

Become a Fellow of BMJ Case Reports today and you can:

- Submit as many cases as you like

- Enjoy fast sympathetic peer review and rapid publication of accepted articles

- Access all the published articles

- Re-use any of the published material for personal use and teaching without further permission

For information on Institutional Fellowships contact consortiasales@bmjgroup.com

Visit casereports.bmj.com for more articles like this and to become a Fellow 